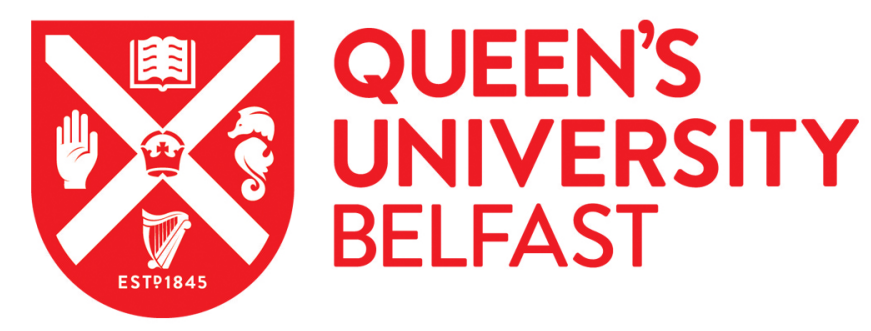

\title{
Improving the wellbeing of staff who work in palliative care settings: a systematic review of psychosocial interventions
}

Hill, R. C., Dempster, M., Donnelly, M., \& McCorry, N. K. (2016). Improving the wellbeing of staff who work in palliative care settings: a systematic review of psychosocial interventions. Palliative Medicine. https://doi.org/10.1177/0269216316637237

Published in:

Palliative Medicine

Document Version:

Peer reviewed version

Queen's University Belfast - Research Portal:

Link to publication record in Queen's University Belfast Research Portal

Publisher rights

Copyright 2016 The Authors

\section{General rights}

Copyright for the publications made accessible via the Queen's University Belfast Research Portal is retained by the author(s) and / or other copyright owners and it is a condition of accessing these publications that users recognise and abide by the legal requirements associated with these rights.

Take down policy

The Research Portal is Queen's institutional repository that provides access to Queen's research output. Every effort has been made to ensure that content in the Research Portal does not infringe any person's rights, or applicable UK laws. If you discover content in the Research Portal that you believe breaches copyright or violates any law, please contact openaccess@qub.ac.uk. 


\title{
Improving the wellbeing of staff who work in palliative care settings: a systematic review of psychosocial interventions
}

\begin{abstract}
Background: Staff in palliative care (PC) settings perform emotionally demanding roles which may lead to psychological distress including stress and burnout. Therefore, interventions have been designed to address these occupational risks.
\end{abstract}

Aim: To investigate quantitative studies exploring the effectiveness of psychosocial interventions that attempt to improve psychological wellbeing of PC staff.

Design: A systematic review was conducted according to methodological guidance from UK Centre for Reviews and Dissemination (2009).

Data Sources: A search strategy was developed based on initial scans of PC studies. Potentially eligible research papers were identified by searching the following databases: CINAHL, MEDLINE (Ovid), PsycINFO \& Web of Science. Two reviewers independently screened studies against pre-set eligibility criteria. To assess quality, both researchers separately assessed the remaining studies using the Quality Assessment Tool for Quantitative Studies .

Results: 1786 potentially eligible papers were identified - 9 remained following screening and quality assessment. Study types included two randomised controlled trials (RCTs), two non-RCT designs, four one-group pre-post evaluations, and one process evaluation. Studies took place in United States of America and Canada (5), Europe (3) and Hong Kong (1). Interventions comprised a mixture of relaxation, education, support and cognitive training 
and targeted: stress, fatigue, burnout, depression and satisfaction. The RCT evaluations didn't improve psychological wellbeing of PC staff. Only two of the quasi-experimental studies appeared to show improved staff wellbeing though these studies were methodologically weak.

Conclusions: There is an urgent need to address the lack of intervention development work and high quality research in this area.

\section{Keywords}

Palliative Care, Staff, Psychosocial Intervention, Wellbeing

\section{What is already known about the topic?}

- $\quad$ Staff working within PC settings can suffer from stress and burnout

- Researchers have advocated the use of psychosocial interventions to improve staff wellbeing and/or reduce staff distress.

- It is not known however whether psychosocial interventions with staff in PC have been successful.

\section{What this paper adds?}

- This is the first review of the effectiveness of psychosocial interventions that attempt to improve the psychological wellbeing of PC staff. The review has established that there is limited research, which is of inadequate quality to establish the effectiveness of psychosocial interventions to improve the psychological wellbeing of PC staff

\section{Implications for practice, theory or policy?}

- This review demonstrates it is impossible at this time to recommend or promote any specific psychosocial intervention.

- Well-designed research, following MRC guidelines, is needed to create, develop and evaluate psychosocial interventions to improve the psychological wellbeing of PC staff.

\section{Background}


There has been a substantial amount of research, addressing the quality of life (QOL) and psychological wellbeing of both patients and their family caregivers in the palliative care (PC) context. ${ }^{1,2}$ However, there is relatively little research to address the psychological wellbeing of the staff in these settings. Staff support is a vital issue in PC as employers have a legal and moral responsibility to ensure staff wellness ${ }^{3}$ and staff wellbeing affects quality of patient care. $^{4,5}$

PC work has numerous emotional demands that may lead to staff stress, including absorption of negative emotional responses, breaking bad news, challenges to personal beliefs, coping with inability to cure, immersion in emotional clashes, poorly defined roles, recurrent exposure to death, working in an area of uncertainty, patient suffering, and secondary trauma. ${ }^{6-8}$ Ultimately, these demands affect staff emotional management, ${ }^{9}$ and it is estimated that $50 \%$ of PC staff are at risk of poor psychological outcomes as a result of insufficient ability to cope with these demands. ${ }^{10}$

This review aims to examine quantitative studies to explore the effectiveness of psychosocial interventions designed to improve psychological outcomes for PC staff. However, there is no clear consensus in the literature of what constitutes a psychosocial intervention or a psychological outcome. Psychosocial interventions are defined broadly as interventions that aim to modify psychological or social factors as opposed to biological ones ${ }^{11}$ or more specifically as any approach involving cognitive-behavioural techniques, stress management, relaxation training, education, hypnosis, or other experiential techniques. ${ }^{12}$ The latter definition is employed in this review.

Psychological outcomes are defined in this review as both the extent to which a person experiences psychological distress or the extent to which a person experiences positive affective states. ${ }^{13}$ Psychological distress can be operationalised in many ways, for example, as 
anxiety or depression and, often within the PC literature, as stress and burnout. ${ }^{14,15}$ Yet, stress is another ambiguous term defined in several ways: a stimulus or pressure bearing down on the person; ${ }^{16}$ a psychological response to a social situation, which can result, if unalleviated, in ill-health; ${ }^{3}$ the ongoing interaction between a person and a situation ${ }^{17}$. Although definitions differ, research suggests that there are adverse effects on psychological outcomes for staff working in PC. Research has found 63\% of health care staff working within inpatient oncology and PC experienced a great deal of stress. ${ }^{18}$ Hence, it has been recommended that interventions are required either to prevent stress from arising or to reduce existing stress to improve the psychological wellbeing of staff, ${ }^{3}$ and that employers and managers have a vital role to train their staff to utilize effective coping techniques ${ }^{19,20}$, with recent qualitative research suggesting a skill-building intervention approach giving staff skills to utilize during work would make a meaningful impact on staff wellbeing, ${ }^{, 21}$

One negative outcome of stress is burnout. ${ }^{22}$ Burnout is characterised by cynicism, exhaustion and inefficacy ${ }^{23}$ and has been conceived as an erosion of wellbeing. ${ }^{24}$ In one study, $25 \%$ of PC nurses had high burnout levels, ${ }^{25}$ which is similar to burnout levels in other health care settings. ${ }^{26}$ More recently, cross-sectional research suggests burnout and psychological morbidity are significant issues for PC practitioners ${ }^{19}$, but there is some evidence to suggest that the use of preventative strategies can address this. ${ }^{27}$

Despite empirical evidence highlighting the emotional risks inherent in PC work, this has not appeared to transform practice in any meaningful way. ${ }^{10}$ Researchers have expressed a need for directed interventions to improve psychological wellbeing and for rigorous outcome evaluation ${ }^{28}$ It is the aim of this review to investigate the extent to which rigorously evaluated interventions exist in this area.

\section{Aim}


To investigate quantitative studies that have explored the effectiveness of psychosocial interventions that attempt to improve psychological outcomes for staff working within PC settings.

\section{Methods}

\section{Design}

A systematic review was conducted, following guidance from the UK Centre for Reviews and Dissemination (2009). ${ }^{29}$ Our eligibility criteria specified that only studies published in English were to be included in the review.In terms of research methodology we were interested in studies that utilized quantitative methods as this better enabled conclusions about the intervention's effectiveness. The other inclusion criteria follow from the objective of the review: participants were staff (paid or voluntary) working within all PC settings (i.e. hospices, hospitals, and community settings); outcomes had to be psychological outcomes for staff, as defined earlier; and interventions had to be psychosocial, as defined earlier. An important aspect of our definition of psychosocial interventions is that there had to be an experiential and reflective component. For example, an art class for PC staff would not meet our definition of psychosocial intervention, but an art class which included some reflection on the experience, would meet our definition.

\section{Data Sources}

Databases were searched from CINAHL (from 1806), PsychINFO (from 1806), MEDLINE (from 1946), and Web of Science (from 1970) for articles published up until $13^{\text {th }}$ March 2015. We used the key thesaurus search terms "Palliative Care OR Hospice” AND “Psychotherapy” AND “Psychological distress OR Wellbeing”. The thesaurus, or medical subject heading, search terms were chosen as they were broad in their scope; for example, in 
the MEDLINE search “psychotherapy” included art therapy, behaviour therapy (cognitive, relaxation, etc.), hypnosis, music therapy, etc. However, search terms were adapted, when necessary, for specific databases to ensure the search was as comprehensive as possible (see Appendix 1) as different key terms cover different topics in different databases Grey literature was searched using the OpenGrey database but this did not identify any relevant articles; neither did searches of the reference lists of included studies generate any additional relevant studies.

\section{Data extraction and quality assessment}

The first reviewer assessed titles and abstracts of all articles found via the database searches and full text articles were obtained for studies that were potentially eligible. The second reviewer then examined the titles and abstracts of all the articles to ensure agreement in terms of exclusion. The two reviewers only disagreed about 1 article, which was resolved by discussion. To assess the studies’ quality, both researchers then separately assessed the remaining full text studies, after which disagreements were discussed until agreement was reached. The Quality Assessment Tool for Quantitative Studies was used; this tool was developed in Canada by the Effective Public Health Practice Project ${ }^{30}$ to assess both the internal and external validity of studies, and has been found to be a reliable and valid tool. ${ }^{31}$

\section{Results}

\section{Study characteristics}

The searches within the four databases revealed 1786 articles, which were all screened. 1746 of these were rejected as, through reading the title and/or abstract, it was apparent that they did not meet the eligibility criteria. A total of 40 articles were then accessed for inclusion on the basis of their full text, and when duplicate articles were removed, 34 remained. A total of 
24 articles were excluded because: there was no psychosocial intervention; the intervention was not for the benefit of PC staff but for patients; they did not include a psychological outcome measure; the intervention was not evaluated A total of 10 articles remained, describing 9 studies which were incorporated into the review. For pictorial representation of this process, see figure 1.

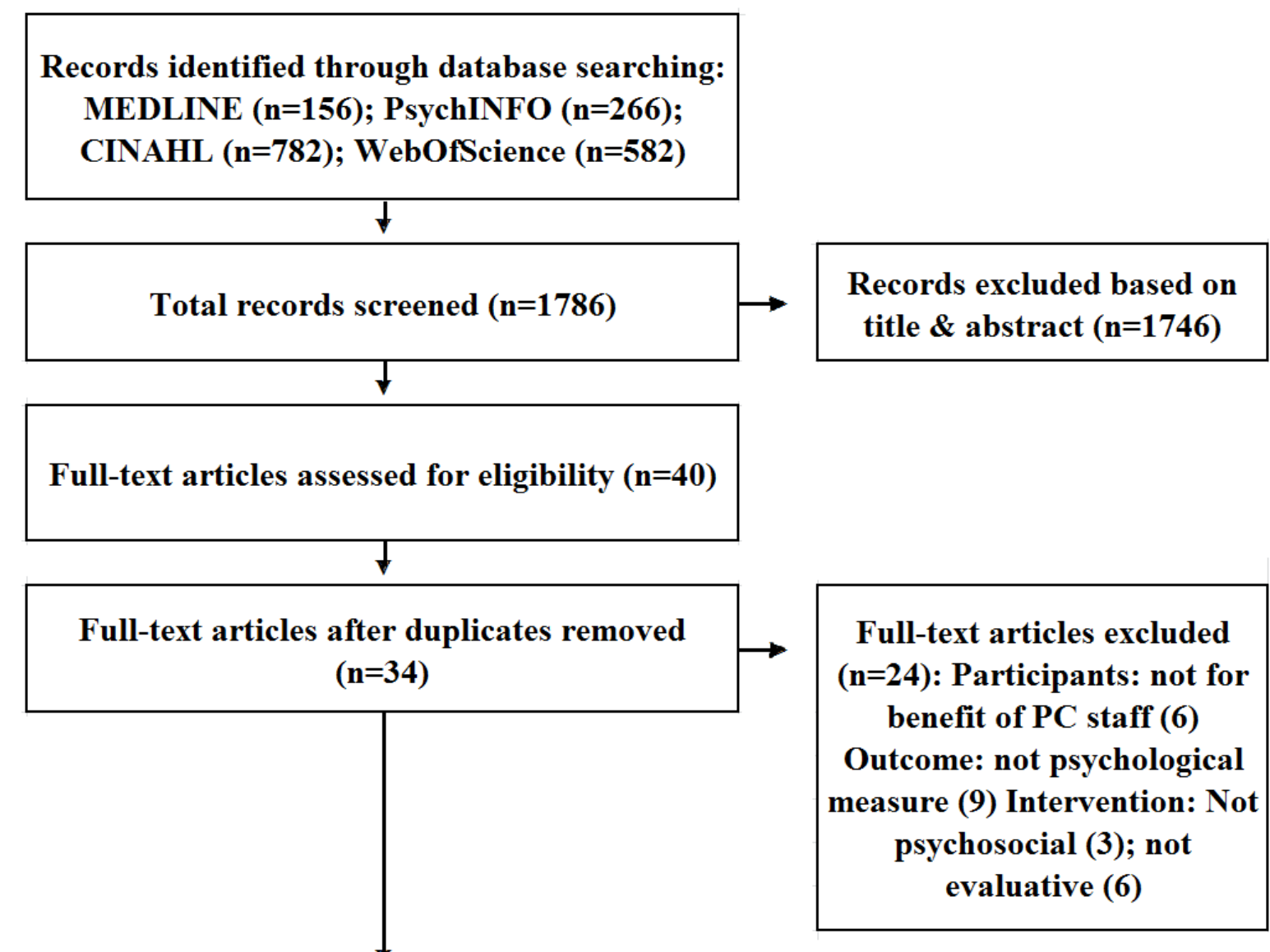

\section{0 articles, describing 9 studies, in review}

Figure 1. Flow diagram of study selection for the review.

There were a variety of different psychosocial interventions used in the studies including: an organizational-level intervention to aid staff wellbeing; ${ }^{32}$ a stress-reduction program; ${ }^{33}$ groupbased music therapy; ${ }^{34,35}$; a psycho-existential intervention; ${ }^{36,37}$ a group-based behavioural sleep intervention; ${ }^{38,38}$; and art therapy. ${ }^{40,41}$ See table 1 for detail about the studies design and 
context and see table 2 for information on intervention content, proposed mechanisms, targeted outcomes, and methods of delivery.

Table 1: Study design \& context

\begin{tabular}{|c|c|c|c|}
\hline \multicolumn{2}{|c|}{ Study } & \multicolumn{2}{|c|}{ Context } \\
\hline Authors & Design & Sample & Location \\
\hline $\begin{array}{l}\text { van Staa et al. } \\
\quad(2000)^{32}\end{array}$ & $\begin{array}{l}\text { Process } \\
\text { evaluation }\end{array}$ & $\begin{array}{c}24 \text { members of staff in } \\
\text { various roles within a } \\
\text { PC unit }\end{array}$ & PCU in Rotterdam \\
\hline $\begin{array}{l}\text { Bruneau \& Ellison } \\
\qquad(2004)^{33}\end{array}$ & $\begin{array}{l}\text { One group pre- } \\
\text { post design }\end{array}$ & 18 nurses providing PC & $\begin{array}{l}\text { UK NHS community } \\
\text { hospital }\end{array}$ \\
\hline Hilliard (2006) & $\begin{array}{l}\text { Two group quasi- } \\
\text { experimental } \\
\text { design }\end{array}$ & $\begin{array}{c}17 \text { nurses, social } \\
\text { workers, \& chaplains } \\
\text { in hospice }\end{array}$ & $\begin{array}{l}\text { Hospice in New } \\
\text { York, USA }\end{array}$ \\
\hline $\begin{array}{l}\text { Fillion, Duval, } \\
\text { Dumont, Gagnon, } \\
\text { Tremblay, Bairati, \& } \\
\text { Breitbart (2009) }\end{array}$ & $\begin{array}{c}\text { Randomized } \\
\text { controlled design }\end{array}$ & 109 PC nurses & Quebec, Canada \\
\hline $\begin{array}{l}\text { Melo \& Oliver } \\
\qquad(2011)^{37}\end{array}$ & $\begin{array}{l}\text { One group pre- } \\
\text { post design }\end{array}$ & $\begin{array}{l}150 \text { healthcare workers } \\
\text { who care for the dying }\end{array}$ & Portugal \\
\hline $\begin{array}{l}\text { Salzano, Lindemann, } \\
\text { \& Tronsky }(2013)^{40}\end{array}$ & $\begin{array}{l}\text { One group pre- } \\
\text { post design }\end{array}$ & 20 hospice caregivers & $\begin{array}{c}\text { Hospice in Northeast } \\
\text { USA }\end{array}$ \\
\hline $\begin{array}{l}\text { Carter, Dyer, \& } \\
\text { Mikan }(2013)^{38}\end{array}$ & $\begin{array}{l}\text { One group pre- } \\
\text { post design }\end{array}$ & $\begin{array}{c}9 \text { agency hospice } \\
\text { nurses }\end{array}$ & $\begin{array}{c}\text { Hospice in central } \\
\text { Texas }\end{array}$ \\
\hline Wlodarczyk (2013) ${ }^{35}$ & $\begin{array}{c}\text { Randomized } \\
\text { controlled design }\end{array}$ & 68 hospice employees & $\begin{array}{l}\text { Hospice in the } \\
\text { Southeast USA }\end{array}$ \\
\hline
\end{tabular}




\begin{tabular}{|c|c|c|c|}
\hline $\begin{array}{l}\text { Potash, Ho, Chan, } \\
\text { Wang, \& Cheng } \\
(2014)^{41}\end{array}$ & $\begin{array}{l}\text { Two group quasi- } \\
\text { experimental } \\
\text { design }\end{array}$ & $\begin{array}{l}132 \text { PC workers (69 in } \\
\text { art-therapy group, } 63 \\
\text { in standard skills-based }\end{array}$ & $\begin{array}{c}\text { Various settings in } \\
\text { Hong Kong }\end{array}$ \\
\hline
\end{tabular}


Table 2: Intervention content, mechanism, outcomes, \& delivery

\begin{tabular}{|c|c|c|c|c|}
\hline Study & Intervention content & Proposed mechanism & $\begin{array}{c}\text { Target outcome } \\
\text { measure relating to } \\
\text { wellbeing }\end{array}$ & $\begin{array}{l}\text { Method of } \\
\text { delivery }\end{array}$ \\
\hline $\begin{array}{l}\text { van Staa, et } \\
\text { al }(2000)^{32}\end{array}$ & $\begin{array}{l}\text { Group-based training \& support. } \\
\text { Team building, support meetings, } \\
\text { relaxation exercise, \& expression of } \\
\text { feelings \& emotions }\end{array}$ & $\begin{array}{c}\text { Support to enhance } \\
\text { growth, give emotional } \\
\text { support \& deal with grief }\end{array}$ & $\begin{array}{l}\text { A researcher designed } \\
\text { stress measure }\end{array}$ & $\begin{array}{c}90 \text { minute } \\
\text { weekly meetings } \\
\text { from January till } \\
\text { December } 1996 \text {, } \\
\text { led by } 2 \\
\text { therapists }\end{array}$ \\
\hline $\begin{array}{l}\text { Bruneau \& } \\
\text { Ellison } \\
(2004)^{33}\end{array}$ & $\begin{array}{l}\text { Stress-reduction program. } \\
\text { Psychoeducation, cognitive coping } \\
\text { skills \& relaxation techniques }\end{array}$ & $\begin{array}{l}\text { Providing coping skills } \\
\text { to reduce stress }\end{array}$ & $\begin{array}{c}\text { Nurses Stress Scale } \\
\left(\mathrm{NSS}^{45}\right)\end{array}$ & $\begin{array}{c}\text { Two } 2 \text { hour } \\
\text { sessions, } 4 \\
\text { weeks apart, led } \\
\text { by } 2 \text { experienced } \\
\text { health } \\
\text { practitioners }\end{array}$ \\
\hline $\begin{array}{l}\text { Hilliard } \\
(2006)^{34}\end{array}$ & $\begin{array}{l}\text { Group-based music therapy. } \\
\text { Music-based meditative relaxation, } \\
\text { psychoeducation, CBT, humanist } \\
\text { approach, stress management, team } \\
\text { building \& coping skills }\end{array}$ & $\begin{array}{l}\text { Using music to foster } \\
\text { team building \& } \\
\text { facilitate coping }\end{array}$ & $\begin{array}{c}\text { Compassion } \\
\text { Satisfaction/Fatigue } \\
\text { Self-Test for Helpers } \\
\left(\mathrm{CFS}^{43}\right)\end{array}$ & $\begin{array}{l}\text { Six weekly } 1 \\
\text { hour music } \\
\text { therapy sessions, } \\
\text { led by music } \\
\text { therapists }\end{array}$ \\
\hline $\begin{array}{l}\text { Fillion, et al. } \\
\qquad(2009)^{36}\end{array}$ & $\begin{array}{c}\text { Existential intervention. } \\
\text { Guided reflections, experiential } \\
\text { exercises, \& education based on } \\
\text { logotherapy }\end{array}$ & $\begin{array}{l}\text { Providing skills to cope } \\
\text { with emotional \& } \\
\text { existential demands }\end{array}$ & $\begin{array}{l}\text { Shortened Profile of } \\
\text { Mood States (POMS- } \\
37^{47} \text { ) }\end{array}$ & $\begin{array}{l}\text { Four weekly } \\
\text { meetings, led by } \\
\text { psychologists }\end{array}$ \\
\hline $\begin{array}{l}\text { Melo \& } \\
\text { Oliver } \\
(2011)^{37}\end{array}$ & $\begin{array}{l}\text { Psycho-existential training. } \\
\text { Psychoeducation - on death anxiety, } \\
\text { the psychology of dying, \& } \\
\text { difficulties in communication }\end{array}$ & $\begin{array}{c}\text { Enabling people to } \\
\text { address their death } \\
\text { anxiety \& improve staff } \\
\text { well-being }\end{array}$ & $\begin{array}{l}\text { A researcher designed } \\
\text { burnout measure }\end{array}$ & $\begin{array}{l}6 \text { day course, led } \\
\text { by a person- } \\
\text { centred therapist }\end{array}$ \\
\hline $\begin{array}{l}\text { Salzano, et } \\
\text { al. }(2013)^{40}\end{array}$ & $\begin{array}{l}\text { Group art-making experience. } \\
\text { Participants worked in pairs to create } \\
\text { quilt panels, then as a team join these } \\
\text { together \& then reflected on } \\
\text { experience }\end{array}$ & $\begin{array}{l}\text { Uses social support to } \\
\text { improve well-being }\end{array}$ & $\begin{array}{l}\text { Maslach Burnout } \\
\text { Inventory }\left(\mathrm{MBI}^{42}\right)\end{array}$ & $\begin{array}{l}\text { One } 1 \text { hour } \\
\text { session, } \\
\text { researcher led }\end{array}$ \\
\hline $\begin{array}{l}\text { Carter, et al. } \\
(2013)^{38}\end{array}$ & $\begin{array}{c}\text { Group-based behavioural sleep } \\
\text { intervention. } \\
\text { Cognitive therapy, stimulus control, } \\
\text { sleep hygiene, \& relaxation } \\
\text { techniques }\end{array}$ & $\begin{array}{l}\text { Improving sleep quality } \\
\text { should reduce insomnia } \\
\text { \& prevent depression \& } \\
\text { burnout }\end{array}$ & $\begin{array}{l}\text { Center for } \\
\text { Epidemiological } \\
\text { Studies-Depression } \\
\left(\text { CES-D }{ }^{46}\right)\end{array}$ & $\begin{array}{l}\text { Two } 1 \text { hour } \\
\text { educational } \\
\text { sessions }\end{array}$ \\
\hline $\begin{array}{l}\text { Wlodarczyk } \\
(2013)^{35}\end{array}$ & $\begin{array}{l}\text { Group-based music therapy. } \\
\text { Group music intervention for grief } \\
\text { resolution }\end{array}$ & $\begin{array}{l}\text { Offers a means to work } \\
\text { through grief }\end{array}$ & $\begin{array}{l}\text { Hospice Clinician } \\
\text { Grief Inventory } \\
\left(\mathrm{HCHI}^{44}\right)\end{array}$ & $\begin{array}{l}\text { One } 1 \text { hour } \\
\text { session, } \\
\text { researcher led }\end{array}$ \\
\hline $\begin{array}{l}\text { Potash, et al. } \\
\qquad(2014)^{41}\end{array}$ & $\begin{array}{c}\text { Art-therapy-based supervision. } \\
\text { Art group - breathing exercise, } \\
\text { guided visualisation, art, reflective } \\
\text { writing, \& discussions. } \\
\text { Skills group - learned new clinical } \\
\text { skills, shared cases \& case analysis }\end{array}$ & $\begin{array}{l}\text { Reduces exhaustion by } \\
\text { enhancing emotional } \\
\text { awareness \& reducing } \\
\text { death anxiety }\end{array}$ & $\mathrm{MBI}^{42}$ & $\begin{array}{c}\text { Art therapy - Six } \\
3 \text { hour weekly } \\
\text { sessions, led by } \\
\text { an art therapist. } \\
\text { Skills-based - } \\
\text { Three } 6 \text { hour } \\
\text { daily sessions, } \\
\text { led by a } \\
\text { counselling } \\
\text { psychologist \& } \\
\text { nurse consultant }\end{array}$ \\
\hline
\end{tabular}




\section{Effectiveness of interventions}

Many of the interventions failed to do what they aimed to do - the support group, the stress reduction program, the meaning-centred intervention, and a cognitive behavioural sleep intervention all failed to significantly improve psychological outcomes (though some did offer some secondary benefits). Nor did they demonstrate a moderate effect (defined as an effect size (ES) of at least 0.30 ). Art therapy ${ }^{41}$ and didactic music therapy ${ }^{34}$ demonstrated a moderate improvement in psychological outcomes. Additionally, it should be highlighted that the majority of authors indicate that psychological wellbeing was not significantly impaired on the outcome measure pre-intervention ${ }^{33-37}$, or else this wasn't clear. ${ }^{40,41}$ However in one study staff were at an increased risk of major depression ${ }^{38}$ and in another, staff were suffering high stress levels. ${ }^{32}$ See table 3 for additional details regarding ESs and secondary findings.

Table 3: Overall effectiveness of the psychosocial interventions reviewed

\begin{tabular}{|c|c|c|}
\hline Intervention & Improved psychological wellbeing? & Secondary findings? \\
\hline $\begin{array}{l}\text { van Staa et al. } \\
(2000)^{32} \text { - Caring } \\
\text { for caregivers } \\
\text { support group }\end{array}$ & $\begin{array}{l}\text { For pre-post scores on the researcher's } \\
\text { designed stress measure: } \\
\text { Support group } \mathbf{E S}=\mathbf{- 0 . 8 1}\end{array}$ & N/A \\
\hline $\begin{array}{l}\text { Bruneau \& } \\
\text { Ellison (2004) } \\
\text { Stress reduction } \\
\quad \text { program }\end{array}$ & $\begin{array}{l}\text { For pre-post scores on the NSS }{ }^{45} \text { : } \\
\text { Stress reduction } \boldsymbol{E S}=\mathbf{0 . 1 5}\end{array}$ & $\begin{array}{l}100 \% \text { of staff valued } \\
\text { the cognitive } \\
\text { restructuring \& 10/15 } \\
\text { liked the Progressive } \\
\text { muscle relaxation }\end{array}$ \\
\hline $\begin{array}{l}\text { Hilliard }(2006)^{34}- \\
\text { Music therapy }\end{array}$ & $\begin{array}{l}\text { For pre-post on the } \mathrm{CFS}^{43} \text { : } \\
\text { Ecological Music therapy } E S=0.01 \text {; } \\
\text { Didactic Music therapy } E S=0.32\end{array}$ & $\begin{array}{l}\text { Significant } \\
\text { improvement in team } \\
\text { building in both } \\
\text { groups }\end{array}$ \\
\hline $\begin{array}{l}\text { Fillion, et al. } \\
(2009)^{36}- \\
\text { Meaning-centered } \\
\text { intervention }\end{array}$ & $\begin{array}{l}\text { For pre-post scores on POMS- } 37^{47} \text { : } \\
\text { Meaning-centred intervention } E S=0.10 \text {; } \\
\text { Waiting-list control group } E S=0.26\end{array}$ & $\begin{array}{l}\text { Experimental group } \\
\text { reported more } \\
\text { perceived benefits of } \\
\text { working in PC }\end{array}$ \\
\hline $\begin{array}{l}\text { Melo \& Oliver } \\
(2011)^{37} \text { - Course } \\
\text { to reduce death } \\
\text { anxiety }\end{array}$ & $\begin{array}{l}\text { For pre-post scores on the emotional } \\
\text { exhaustion scale of the researcher's } \\
\text { designed burnout measure: } \\
\text { Death anxiety course } \boldsymbol{E S}=\mathbf{0 . 2 6}\end{array}$ & $\begin{array}{l}\text { Increase in } \\
\text { professional fulfilment } \\
\text { \& improved quality of } \\
\text { relationships with } \\
\text { patients \& families }\end{array}$ \\
\hline
\end{tabular}


For pre-post scores on the $\mathrm{MBI}^{42 *}$

(Maslach, Jackson, \& Leiter, 1996):

\begin{tabular}{|c|c|}
\hline $\begin{array}{l}\text { Salzano, et al. } \\
(2013)^{40}- \\
\text { Collaborative art- } \\
\text { making }\end{array}$ & $\begin{array}{l}\text { emotional exhaustion subscale: } \\
\text { Art-making group ES }=0.09^{* *} \text {; } \\
\text { Control group } E S=0.01^{* *} \\
\text { cynicism subscale: } \\
\text { Art-making group ES }=0.04^{* *} \\
\text { Control group } E S=-0.11^{* *}\end{array}$ \\
\hline $\begin{array}{c}\text { Carter, et al. } \\
(2013)^{38}- \\
\text { Cognitive } \\
\text { behavioural sleep } \\
\text { intervention }\end{array}$ & $\begin{array}{l}\text { For pre-post score on CES-D }{ }^{46} \text { : } \\
\text { Sleep intervention } \boldsymbol{E} \boldsymbol{S}=\mathbf{0 . 2 6}\end{array}$ \\
\hline $\begin{array}{c}\text { Wlodarczyk } \\
(2013)^{35} \text { - Group } \\
\text { music } \\
\text { intervention }\end{array}$ & $\begin{array}{l}\text { For pre-post grief scores on the } \mathrm{HCHI}^{44} \\
\text { Group-Music intervention } \mathbf{E S}=\mathbf{0 . 0 7} \\
\text { Control group } \boldsymbol{E S}=* * *\end{array}$ \\
\hline
\end{tabular}

For pre-post scores on $\mathrm{MBI}^{42 *}$ : emotional exhaustion subscale:
Potash, et al. $(2014)^{41}$ - Art therapy

\author{
Experimental group \\ showed an increase in \\ work support measures \\ On-site delivery was \\ valued \& people \\ valued the intervention
}
Significant decline for participants on the subscale measure personal sacrifice burden

Art therapy group showed increased emotional awareness

\footnotetext{
* It was not possible to work out the ES for the entire measure, as there was insufficient detail given. It was possible to obtain ESs for the emotional exhaustion \& cynicism subscales, the professional efficacy subscale wasn't significantly different in either of these 2 studies. ** Whilst this study did not give standard deviations (SDs) for the experimental or control group the ESs were worked out using the SDs from the Potash et al. (2014) $)^{41}$ study as they also found significant differences in the emotional exhaustion and cynicism subscale of the MBI (Maslach, et al. 1996).

***This study did not have a control group score at pre-test so it was not possible to work out the ES for the control group.
}

\section{Methodological quality}

An important consideration of any systematic review is methodological quality. The methodological quality of the quantitative studies was assessed by two researchers using the Quality Assessment Tool for Quantitative Studies, ${ }^{30}$ which provides an overall rating of weak, moderate or strong quality for each study. Overall only two ${ }^{35,36}$ of the nine studies were of sufficient quality to be rated as moderate and the remainder were considered weak. All studies included were prone to selection bias, as the participants were self-selecting in choosing to participate in the interventions. In contrast, a general strength was that all studies, except two, ${ }^{32,37}$ utilized valid and reliable measures for assessing outcomes. The primary difference between the weak and moderate studies lay in the strength of their research design, 
with the two moderate studies using RCT designs, ${ }^{35,36}$ although one of these studies ${ }^{35}$ did not include a pre-test of the control group, thereby compromising the internal validity of the study.

\section{Outcome measures}

The quantitative studies utilized a range of measures to assess psychological distress and wellbeing. A twice utilized measure was the Maslach Burnout Inventory ( $\left.\mathrm{MBI}^{42}\right){ }^{40,41}$ The remaining studies utilized a range of measures: the Compassion Satisfaction/Fatigue SelfTest for Helpers $\left(\mathrm{CFS}^{43}\right) ;{ }^{34}$ the Hospice Clinician Grief Inventory $\left(\mathrm{HCHI}^{44}\right) ;{ }^{35}$ the Nurses Stress Scale (NSS $\left.{ }^{45}\right) ; 3$ the Center for Epidemiological Studies-Depression (CES-D $\left.{ }^{46}\right){ }^{38}$ and the vigour/activity subscale of the Shortened Profile of Mood States (POMS-37 ${ }^{47}$ ). ${ }^{36}$ Finally, two studies used researcher constructed questionnaires to assess stress/burnout and did not utilize a standardised measure. ${ }^{32,37}$

\section{Discussion}

\section{Interpretation of results}

In systematically reviewing psychosocial interventions for PC staff, little evidence was found of adequate quality to evaluate the success of interventions in this area. It is well known that research in $\mathrm{PC}$ is prone to difficulties ${ }^{48}$ so it is perhaps unsurprising that severe methodological issues were apparent in most of these studies.

Randomized controlled trials. Only two of the eleven studies utilized RCTs. Sibbald and Roland emphasise that, due to their important features, RCTs are the most rigorous method for assessing whether there is a causal relationship between a treatment and an outcome; in contrast, other designs can only detect associations - as we cannot exclude the possibility that the effect was due to a third factor. ${ }^{49}$ In the two RCTs the process of randomization was well 
described, although one study lacked a pre-test measure score for the control group. ${ }^{35}$ In these higher quality studies, the effect sizes found for the interventions (a group-music intervention and a meaning-centred intervention) were weak. For the remaining studies, a lack of randomization, and often the lack of a comparison group, prevents us from making any strong inferences about intervention effectiveness.

Outcome measures. Studies used a variety of measures relating to psychological outcomes, and it is therefore difficult to directly compare findings. This raises the issue of what measure should be seen as optimal when assessing psychological outcomes for staff in PC. In other words, which psychological outcomes should be targeted by an intervention? Owing to the fact that stress and burnout are the most common psychological outcomes mentioned in the literature, the $\mathrm{MBI}^{42}, \mathrm{CFS}^{43}$, and the $\mathrm{NSS}^{45}$ could be frontrunners in choosing a valid and reliable measure of psychological outcomes in PC staff.

Sample size and small number of studies. In the reviewed studies, the sample sizes were small (9-150), and the number of studies in general was limited. These limitations hinder the statistical power and undermine the generalizability of the results to other staff working within PC.

Psychosocial interventions. The present review includes a range of psychosocial interventions which propose various psychosocial mechanisms responsible for their effects on wellbeing (see table 2). However, due to the lack of meaningful improvement in many cases, the frameworks underlying these interventions are questionable. It is not clear from the literature reviewed whether the interventions were developed based on a sound model of psychological processes, except in the case of the meaning-centered intervention ${ }^{36}$ in which the authors reference their development work in detail. This modelling phase is the first step in intervention development and, in its absence, the likelihood of an intervention being 
effective reduces. Therefore, this could explain why the interventions reviewed were largely ineffective.

Due to these limitations, we cannot make any conclusive recommendations regarding what psychosocial interventions could meaningfully improve psychological outcomes for staff working within PC settings.

\section{Implications for practice and future research}

Better quality effectiveness research

The results of this systematic review highlights the need for better evaluation of psychosocial interventions for staff which supports the view of Belletti and colleagues, ${ }^{28}$ that PC needs interventions that are effectively evaluated with scientifically based outcome evaluations. Kamau and colleagues ${ }^{10}$ also indicate that research has yet to have a meaningful impact upon practice. The implications of this review are that more research of a higher quality is necessary to evaluate effective psychosocial interventions to improve psychological outcomes for PC staff. A meta-synthesis ${ }^{48}$ focusing on interventions with patients and carers has established that there are many challenges and limitations to carrying out research within PC. Many of these challenges are likely to exist when developing interventions with PC staff such as: inadequate transformation of evidence into practice; methodological challenges make 'pure' RCTs designs difficult to achieve; and studies are often weakened due to selfselection (a problem we found in all studies reviewed). ${ }^{48}$ The same meta-synthesis suggested what would be necessary to ensure best practice in terms of evaluating studies for PC: implementation as a process - taking necessary steps to engage with stakeholders and undertake preparatory work to lessen any implementation concerns; using a precise recruitment strategy; optimising the study design to ensure it is rigorous as possible - 
utilizing RCT methods. ${ }^{48}$ On the basis of the findings in this review, a similar set of recommendations could be made for interventions with PC staff.

\section{Better intervention development}

Psychosocial interventions should be rigorously constructed, developed and implemented using MRC guidelines. ${ }^{50}$ Research with PC staff offers some pertinent information in regard to how to ensure an intervention's success. First of all, interventions should be grounded firmly in sound theoretical roots, validated by experts and piloted with the staff to ensure it meets their needs ${ }^{51}$. Additionally, the skills and methods gained should be of benefit to staff during their working day, for example staff being able to use the skills and techniques of mindfulness in their daily work to support their patients and look after themselves ${ }^{52}$. Finally, a lot of the literature specifically focuses on what makes a support group successful members sharing experiences, establishing relationships, confidentiality, having an allocated time $^{53}$, having self-aware members, having leader involvement, inclusion of clerical and administrative staff, suitable size, being held during working hours, having mandatory attendance, and having a paid outside facilitator. ${ }^{54}$ Future work aiming to design a psychosocial intervention for PC staff should consider and act on these findings to ensure the best chance of successfully improving staff wellbeing.

\section{Strengths and limitations of this review}

This study was carried out using the systematic review method. A multidisciplinary team (psychologist, methodologist, health services researcher, systematic review specialist, palliative care staff) assisted in the generation of the search strategy. Careful searches were carried out using four relevant electronic databases. To ensure inclusion of studies was not 
subjective, inclusion criteria was assessed by two researchers independently. Nevertheless, a number of limitations must be mentioned. First, there is a language bias in that only studies in English were included. Second, it is possible only more positive research was considered due to a publication bias. Due to these reasons, it is possible some studies may have gone unidentified.

\section{Conclusion}

On the basis of this review, it is not feasible to draw any meaningful conclusions about what psychosocial interventions are effective in improving the psychological wellbeing of PC staff. The implications, as discussed, are that the lack of high quality research needs to be addressed and, furthermore, interventions need to be developed more thoughtfully. This review increases awareness of the lack of research, and lack of quality of the research, in this area which means that, as yet, psychological outcomes for PC staff have not been meaningfully improved.

\section{Declaration of conflicting interests}

The authors have no conflict of interest to declare.

\section{Funding}

This study was funded by the Department of Education and Learning (DEL) as part of a PhD studentship. 


\section{$\underline{\text { References }}$}

1. Jaiswal R, Alici Y and Breitbart W. A comprehensive review of palliative care in patients with cancer. International Review of Psychiatry 2014; 26: 87-101.

2. Harding R, List S, Epiphaniou E, et al. How can informal caregivers in cancer and palliative care be supported? An updated systematic literature review of interventions and their effectiveness. Palliative medicine 2012; 26: 7-22.

3. Payne M. Staff Support. In Lloyd-Williams M (ed.) Psychosocial Issues in Palliative Care. $2^{\text {nd }}$ ed. New York: Oxford University Press; 2008; p231-252.

4. Department of Health. NHS Health and Wellbeing review: interim report. London: Department of Health; 2009.

5. Maben J, Peccei R, Adams M, et al. Exploring the relationship between patients' experience of care and the influence of staff motivation, affect and wellbeing. SDO report. Southampton: NIHR; 2012.

6. Rokach A. Caring for those who care for the dying: coping with the demands on palliative care workers. Palliative \& supportive care 2005; 3: 325-332.

7. White K, Wilkes L, Cooper K, et al. The impact of unrelieved patient suffering on palliative care nurses. International Journal of Palliative Nursing 2004; 10: 438-444.

8. Breen LJ, O’Connor M, Hewitt LY, et al. The “specter” of cancer: exploring secondary trauma for health professionals providing cancer support and counseling. Psychological services 2014; 11: 60-67.

9. Uren S and Graham T. Subjective experiences of coping among caregivers in palliative care. OJIN: The Online Journal of Issues in Nursing 2013; 18. doi:10.3912/OJIN.Vol18No02PPT02. (accessed 17 June 2015).

10. Kamau C, Medisauskaite A and Lopes B. Orientations can avert psychosocial risks to palliative staff. Psycho-Oncology 2014; 23: 716-718. 
11. Ruddy R and House A. Psychosocial interventions for conversion disorder. Cochrane Database of Systematic Reviews 2005; 4: 1-27.

12. Gorin SS, Krebs P, Badr H, et al. Meta-analysis of psychosocial interventions to reduce pain in patients with cancer. Journal of Clinical Oncology 2012; 30: 539-547.

13. Deci EL and Ryan RM. Hedonia, eudaimonia, and well-being: an introduction. Journal of Happiness Studies 2008; 9: 1-11.

14. Vachon ML. Four decades of selected research in hospice/palliative care: have the stressors changed? In I. Renzenbring I (ed.) Caregiver Stress and Staff Support in Illness, Dying, and Bereavement. New York: Oxford University Press; 2011; p1-24.

15. Melvin CS. Historical review in understanding burnout, professional compassion fatigue, and secondary traumatic stress disorder from a hospice and palliative nursing perspective. Journal of Hospice \& Palliative Nursing 2015; 17: 66-72.

16. Lazarus R S and Folkman S. Stress, Appraisal, and Coping. New York: Springer; 1984.

17. Lazarus RS. Fifty years of the research and theory of R.S. Lazarus: An analysis of historical and perennial issues. Mahwah, NJ: Erlbaum; 1998.

18. Dougherty E, Pierce B, Ma C, et al. (2009). Factors associated with work stress and professional satisfaction in oncology staff. American Journal of Hospice and Palliative Medicine 2009; 26: 105-111.

19. Koh MYH, Chong PH, Neo PSH, et al. Burnout, psychological morbidity and use of coping mechanisms among palliative care practitioners: A multi-centre cross-sectional study. Palliative Medicine 2015; 29: 633-642.

20. Peters L, Cant R, Sellick K, et al. Is work stress in palliative care nurses a cause for concern? A literature review. International Journal of Palliative Nursing 2012; 18: 561-7. 
21. Perez GK, Haime V, Jackson V., et al. Promoting Resiliency among Palliative Care Clinicians: Stressors, Coping Strategies, and Training Needs. Journal of Palliative Medicine 2015; 18: 332-337.

22. Asai M, Morita T, Akechi T, et al. Burnout and psychiatric morbidity among physicians engaged in end-of-life care for cancer patients: a cross-sectional nationwide survey in Japan. PsychoOncology 2007; 16: 421-428.

23. Maslach C, Schaufeli WB and Leiter MP. Job burnout. Annual review of psychology 2001; 52: 397-422.

24. Schaufeli WB, Leiter MP and Maslach C. Burnout: 35 years of research and practice. Career development international 2009; 14: 204-220.

25. Lissandre S, Abbey-Huguenin H, Bonnin-Scanon S, et al. Facteurs associe's au burnout chez les soignants en oncohématologie. Oncologie 2008; 10: 116-124.

26. Pereira SM, Fonseca AM and Carvalho AS. Burnout in palliative care: literature review. Nursing Ethics 2011; 18: 317-26.

27. Pereira SM, Fonseca AM and Carvalho AS. Burnout in nurses working in Portuguese palliative care teams: a mixed methods study. International journal of palliative nursing, 18, 2012; 18 : 373-381.

28. Belletti M, Mallia L, Lucidi F, et al. Complementary therapy and support services for formal and informal caregivers in Italian palliative care hospices: an exploratory and descriptive study. Supportive Care in Cancer 2011; 19: 1939-1947.

29. Centre for Reviews \& dissemination (CRD). Systematic reviews: CRD's guidance for undertaking reviews in health care. York: Centre for Reviews and Dissemination, University of York; 2009.

30. Effective Public Health Practice Project. Quality Assessment Tool for Quantitative Studies. Hamilton, ON: Effective Public Health Practice Project; 1998. 
31. Thomas BH, Ciliska D, Dobbins $\mathrm{M}$, et al. A process for systematically reviewing the literature: Providing the research evidence for public health nursing interventions. Worldviews on Evidence-Based Nursing 2004; 1: 176-184.

32. Van Staa AL, Visser A and van der Zouwe N. Caring for caregivers: experiences and evaluation of interventions for a palliative care team. Patient Education and Counseling 2000; 41: 93105.

33. Bruneau BM and Ellison GT. Palliative care stress in a UK community hospital: evaluation of a stress-reduction programme. International journal of palliative nursing 2004; 10: 296-304.

34. Hilliard RE. The effect of music therapy sessions on compassion fatigue and team building of professional hospice caregivers. The Arts in psychotherapy 2006; 33: 395-401.

35. Wlodarczyk N. The effect of a group music intervention for grief resolution on disenfranchised grief of hospice workers. Progress in Palliative Care 2013; 21: 97-106.

36. Fillion L, Duval S, Dumont S, et al. Impact of a meaning-centered intervention on job satisfaction and on quality of life among palliative care nurses. Psycho-Oncology 2009; 18: $1300-1310$.

37. Melo CG and Oliver D. Can addressing death anxiety reduce health care workers' burnout and improve patient care? Journal of palliative care 2010; 27: 287-295.

38. Carter PA, Dyer KA and Mikan SQ. Sleep disturbance, chronic stress, and depression in hospice nurses: testing the feasibility of an intervention. Oncology nursing forum 2013; 40: E368E373.

39. Carter P, Dyer K and Mikan S. Behavioral sleep intervention for hospice nurses: A pilot study. In Oncology Nursing Forum 2007; 34:190-191.

40. Salzano AT, Lindemann E and Tronsky LN. The effectiveness of a collaborative art-making task on reducing stress in hospice caregivers. The Arts in Psychotherapy 2013; 40: 45-52. 
41. Potash JS, Ho AH, Chan F, et al. Can art therapy reduce death anxiety and burnout in end-of-life care workers? A quasi-experimental study. International journal of palliative nursing 2014; 20: $233-240$.

42. Maslach C, Jackson SE and Leiter MP. Maslach Burnout Inventory manual ( ${ }^{\text {rd }}$ Ed.). Mountain View, CA: CPP Inc; 1996.

43. Figley CR. Measuring compassion satisfaction as well as fatigue: Developmental history of the Compassion Satisfaction and Fatigue Test. Violence \& Abuse Abstracts 2002; 8: 251-362.

44. Cote T. Evaluating the grief experience in hospice clinicians. Journal of Palliative Medicine 2008; 11: 342-382.

45. Gray-Toft P and Anderson J. The nursing stress scale: development of an instrument. Journal of Behavioural Assessment 1981; 3: 11-23.

46. Radloff LS. The CES-D Scale: A self-report depression scale for research in the general population. Applied Psychological Measurement 1977; 1: 385-401.

47. Shacham S. A shortened version of the Profile of Mood States. Journal of personality assessment 1983; 47: 305-306.

48. Evans CJ, Harding R and Higginson IJ. 'Best practice' in developing and evaluating palliative and end-of-life care services: A meta-synthesis of research methods for the MORECare project. Palliative medicine 2013; 27: 885-898.

49. Sibbald B and Roland M. Understanding controlled trials. Why are randomised controlled trials important? BMJ: British Medical Journal 1998; 316: 201.

50. Craig P, Dieppe P, Macintyre S, et al. Developing and evaluating complex interventions: new guidance. London: Medical Research Council; 2008.

51. Fillion L, Dupuis R, Tremblay I, et al. Enhancing meaning in palliative care practice: a meaningcentered intervention to promote job satisfaction. Palliative and Supportive Care 2006; 4: 333-344. 
52. Bruce A and Davies B. Mindfulness in hospice care: practicing meditation-in-action. Qualitative Health Research 2005; 15: 1329-1344.

53. Feld J and Heyse-Moore L. An evaluation of s support group for junior doctors working in palliative medicine. American Journal of Hospice \& Palliative Medicine 2006; 23: 287-296.

54. Hunsberger P. Creation and evolution of the hospice staff support group: lessons from four longterm groups. American Journal of Hospice Care 1989; 6: 37-41.

\section{Appendix 1 - terms used \& results of database searches}

In all databases the key MESH terms were exploded if the option was offered.

\section{A. MEDLINE}

In medline the search terms used were:

- "Palliative care OR Hospices"

- AND "Psychotherapy"

- AND “Stress, psychological OR Burnout, Professional OR Depression OR Anxiety OR Self Care OR Quality of Life OR Adaptation, Psychological”

o Limited by English

- $\quad$ Search last undertaken on $13^{\text {th }}$ March 2015 - resulted in 156 records:

0 all screened, however on the basis of title and abstract just $\mathbf{6}$ articles were selected for full-text exploration

o 5 were excluded as they didn't meet the inclusion criteria

01 psychosocial intervention with staff

\section{B. CINAHL}

In CINAHL the search terms used were:

- $\quad$ "Palliative care OR Hospice and Palliative Nursing OR Terminal Care OR Hospice Care”

- AND "Psychotherapy OR Psychotherapy, Group”

- $\quad$ AND "Stress OR Depression OR Anxiety OR Quality of life OR Quality of working Life OR Coping OR Psychological wellbeing” ('self-care' was not used as this was found to refer to 'self-care' in a medical rather than psychological sense)

o Limited by peer reviewed

- $\quad$ Search last undertaken on $13^{\text {th }}$ March 2015 - resulted in 782 records:

o all screened, however on the basis of title and abstract 22 articles were selected for full-text exploration

o 15 were excluded as they didn't meet the inclusion criteria 
o 7 psychosocial interventions with staff

\section{PsychINFO}

In PsychInfo the search terms used were:

- "Palliative care OR Hospice"

- AND "Treatment (this was a broader term for therapy) OR Death Education OR Intervention OR Psychoeducation OR Self help techniques OR Stress Management"

- AND “Stress OR Depression (emotion) OR Anxiety OR Wellbeing”

o Limited by English

- $\quad$ Search last undertaken on $13^{\text {th }}$ March 2015 - resulted in 266 hits

0 all screened, however on the basis of title and abstract just 7 articles were selected for full-text exploration

o 3 excluded as they didn't meet inclusion criteria

o 4 psychosocial interventions with staff

D. Web of Science

In Web of Science the search terms used were:

- "Palliat* OR Hospice*”

- AND "Psycho* OR Intervention OR Support*”

- AND “*Stress OR Coping* OR Self*care OR Wellbeing”

- AND "Staff* OR Caregiver OR *Worker"

o Limited by english

- $\quad$ Search last undertaken on $13^{\text {th }}$ March 2015 - resulted in 582

0 all screened, however on the basis of title and abstract just 5 articles were selected for full-text exploration

o 3 didn't meet the inclusion criteria

o 2 psychosocial interventions with staff 